\title{
On History, Archive, and Theory: A Review of Nick Deocampo's Eiga: Cinema in the Philippines During World War II
}

Louise Jashil R. Sonido

There is no political power without control of the archive, if not of memory. Effective democratization can always be measured by this essential criterion: the participation in and the access to the archive, its constitution, and its interpretation.

History and, as a consequence, memory are presumed to rely on archives; and in the absence of an archive compounded by an erasure of memory due to violence and trauma, history comes under a terrible crisis. The circumstances underpinning the study of cinema during World War II confront this crisis squarely as a period remembered in large part for the atrocities the people suffered at the hands of the Japanese imperial army, and mourned for the extensive damage it wrought upon heritage structures, memory institutions, and cultural archives in the bombings that leveled major cities. Of the art forms, cinema suffered a great loss, with all aspects of production compromised during the war and virtually all of its outputs and infrastructures destroyed, leaving little for scholars and archivists more than 70 years later to hark back to and reconstruct. Under these 
conditions, one can expect little of any kind of extensive historiographic work on cinema to emerge, which is precisely what makes the publication of Nick Deocampo's Eiga: Cinema in the Philippines During World War II (2016) a monumental effort in archival work, memory rehabilitation, and historiographic discourse. In its detailing of the conditions of filmmaking and cinematic life during World War II, the book takes the reader through a windfall of archival data yet to be explored in any other locally available resource. But more than its unquestionable value as a contribution to the "[enrichment of] the country's knowledge about its cultural and cinematic heritage" (p. xvii), Eiga also brings to fore vital questions on the politics of identity vis-à-vis ruptured memory and the crisis of recollection in the face of archival loss.

While theoretically, history must proceed from the archives, in the absence of and/or lack of access to a comprehensive film collection surviving World War II, for many a film scholar in the Philippines, Eiga presumes the dual role of both history and archive. Apart from its meticulous detailing of the policies, structures, and institutions that the Japanese colonial government put in place during the war, such as the 1939 Motion Picture Law, the Bunka Senshi and the Eiga Haikyushu, the book also foregrounds records and documents hitherto unknown or under-explored in Philippine history and media scholarship. Included in the revelatory dossier: an inventory of the pre-war movie industry in the Philippines conducted by the propaganda unit of the Japanese army; reel-by-reel accounts of the fulllength films produced by the Japanese in the Philippines, Toyo no Gaika [Victory Song of the Orient], 1942, and Ano Hata o Ute [Dawn of Freedom], 1944; excerpts from the dialogue/script of Sannin no Maria [Tatlong Maria], 1944; oral narratives of the cinema as a space for the subversive activities of underground revolutionaries; and, among Eiga's most remarkable finds, the critical essays of Tsutomu Sawamura on the importance of decolonizing Filipino cinema and building a new national cinema for Filipinos, as well as Hidemi Kon's discourses on "cultural construction," a strategy for cultural warfare that in effect demystified the ideological dimensions of cinema in its attempt to promote Japanese culture and nationalist sentiments among Filipinos. The book then goes into a sampling of post-war films containing cinematicimpressions of the Japanese colonial experience, thereby producing these films as much within a history of cinematic representations of the Japanese in Philippine film history as within a "history of the formation of a concept" (Derrida, 1995, p. 11)-that of the Japanese colonial legacy in Filipino cultural life.

With its rich cache of data, Eiga becomes both historical narrative and written archive, a catalogue of significations of external documents, 
interviews, books, photographs, films, and institutions culled and collected in its discursively produced space. It thereby fulfills what many scholars contend is the integral function of all scholarship: as "implicitly a negotiation with, an interpretation of, and a contribution to the archive" (Manoff, 2004, p. 13). But more than a veritable listing of records, Eiga also marks an important historical moment if we are to conceive of history as archive:

Arkhe we recall, names at once the commencement and the commandment. This name apparently coordinates two principles in one: the principle according to nature or history, there where things commence-physical, historical, or ontological principle-but also the principle according to the law, there where men and gods command, there where authority, social order are exercised, in this place from which order is given-nomological principle. (Derrida, 1995, p. 9)

One might then construe Eiga as the point of commencement of an archive-a crucial first iteration-even as history is typically conceived as a reiteration of archival data that gestures toward the providence of physically existent records preceding its own utterance. However, in the context of Philippine film historiography, the dialectical irony becomes both inevitable and poetic: inevitable, as the ravages of time across a century of almost perpetual warfare, with neither resource nor regard for physical archiving, have rendered too many archivable artefacts in the country irretrievable; and poetic, because the work locates the originary imprints of "Filipino" cinema in the archives of its colonial masters.

Indeed, Eiga's exploration of the intimacy of war and cinema during World War II highlights the extent of material, ideological, and epistemic violence the Philippines suffered as a perpetual collateral in the wars of imperial powers. In the course of mapping the many ways that cinema became an essential front of struggle for the Japanese colonizers to wrest influence from the American colonizers they were superseding, Eiga concretizes how the Philippine nation was treated as a mere battleground for imperial warfare, with the outcomes seemingly dictated less by the upsurge of revolutionary fervor than the inertia of global conflicts between the monolithic hegemonies of the Allied and Axis powers. The archive is a direct symptom of this somatic and ontological displacement of the colonized: the imprints of Filipino nation-formation and the traces of influence shaping Filipino identity, particularly during World War II, are physically located elsewhere and written in languages we can neither write nor pronounce. Thus, for Philippine scholarship, Eiga stands as a critical originary of our World War II cinematic history, a repatriation of our cultural archive, heterogeneous and hybridized though it may be. 
Consequently, Eiga also becomes the nomological space through which people might begin to grasp an archive of cinematic history during World War II, wielding what Jacques Derrida (1995) refers to as an "archontic power" (p. 10):

This archontic function is not solely topo-nomological. It does not only require that the archive be deposited somewhere, on a stable substrate, and at the disposition of a legitimate hermeneutic authority. The archontic power, which also gathers the functions of unification, of identification, of classification, must be paired with what we will call the power of consignation. By consignation, we do not only mean, in the ordinary sense of the word, the act of assigning residence or of entrusting so as to put into reserve (to consign, to deposit), in a place and on a substrate, but here the act of consigning through gathering together signs. (p. 10)

Of course, Derrida would remain, permanently and with good reason, suspicious of the "patriarchal logic" that underpins consignation, but in Eiga where history/narrative/discourse becomes the way to access the archival/ physical/hypomnesic, the jussive is subsumed under the discursive, and memory is, in some sense, unshackled from the oppressive linearity and irresistible "science" of conventional archival historiography. In this way, the archive is self-consciously a "system of discursivity' that establishes the possibility of what can be said" (Michel Foucault, as cited in Manoff, 2004, p. 18). Thus, history in Eiga is not only able to mean what it says, but also to signify toward what else can be written.

While the discursive unity that anchors Deocampo's multi-volume saga on motion picture history is the question of national identity as it contends with and is vexed by the multiple colonial experiences the nation underwent, his historiographic method enables questions beyond the research's own problematique. In fact, the remarkable contradictions that surface when one, for instance, confronts the blood trail of the 1942 Bataan Death March side by side with Tsutomu Sawamura's exhortations to "truth, goodness, and beauty" in the "ideal" Filipino cinema, points toward matters of significant historical import that exceed the central question of the project. Despite the persistence of the theme of constructed nationalisms and negotiated identities, what strikes more powerfully is the luminous richness of Deocampo's historiographic process, which, in the course of archiving the nation in cinematic history, also mobilizes history as theory-a way of creating limits to enable productive excesses. Indeed, 
the project seems underpinned by an ostensibly Marxist aspiration despite its more apparent postcolonial concerns: the material archive is the way to ideal self-recognition, and understanding the precise nature of the archive, defined as it is as much by its gaps as its circuitous revelations, is key to unfettering history from the memory lapses of historical trauma.

Monumental in its sheer fortitude, Eiga renames archival absence as a series of historiographic detours and the crisis of recollection as the conducive condition for discursive agency. Thus, remarkably, in the face of the "reality' of the past which is 'always already' lost" (Dominick LaCapra, as cited in Manoff, 2004, p. 14), we might begin to revel in inheriting nothing but the emancipatory possibilities of seeking, and the will to locate power in yet unexplored sites of memory-our archive fever and compulsive nostalgia ever irrepressible, incessant, but always revolutionary. 


\section{References}

Deocampo, N. (2016). Eiga: Cinema in the Philippines during World War II. Manila : Anvil Publishing.

Derrida,J. (1995). Archive fever:A Freudian impression (E.Prenowitz, trans.). Diacritics 25(2):9-63. Retrieved from http://www.jstor.org/stable/465144.

Manoff, M. (2004). Theories of the archive from across the disciplines. Portal: Libraries and the Academy 4(1): 9-25. Retrieved from https://muse.jhu.edu/article/51302.

LOUISE JASHIL R.SONIDO is an instructor at the Department of English and Comparative Literature of the University of the Philippines (UP), Diliman, a graduate student at the UP College of Mass Communication, and a member of the Congress of Teachers and Educators for Nationalism and Democracy (CONTENDUP). She is also a multimedia artist and a cultural worker (corresponding author:Irsonido@gmail.com). 